\title{
A destination or a place of last resort? The research library of the future, its users and its librarians
}

Pat Gannon-Leary, Moira Bent and Jo Webb

\section{Introduction}

This speculative and reflective article is based on themes discussed within the literature, interviews with researchers and our own thoughts, developed during our research for a book (Webb et al., 2007) and our experience as practitioners. Themes explored include research spaces, marketing, eResearch and Library 2.0, users of the future, research support and the future role of the librarian.

\section{Research spaces}

Twenty years ago, working spaces in a university library comprised individual study carrels, possibly bookable and enclosed, discrete spaces to use technology, often in the form of catalogue terminals and a few computers, in addition to open reading room spaces. Some libraries also provided common rooms and cafes outside the study area.

During the 1990s, more university libraries incorporated information technology, usually in dedicated IT zones, and more of their activities, ranging from library management to information resources, became focused on information and communications technology. The provision of spaces for group study also became the norm. Noisier activities started to centre on the library as a physical space. Service convergence, with computing and also student learning support, became common in the UK.

\section{Authors}

Pat Gannon-Leary is a Research Associate in Learning \& Teaching Support, Academic Registry, Northumbria University. Summaries of some of her pedagogical research may be found at http://northumbria.ac.uk/sd/central/ar/lts/enhance/pedagogic/?view=Standard

Email: pat.gannon-leary@unn.ac.uk

Moira Bent is Science Librarian at Newcastle University and a National Teaching Fellow. Publications and current activities can be found at http://blogs.ncl.ac.uk/moira.bent

Jo Webb is Academic Services Manager at De Montfort University. She is responsible for subject liaison and learning development services, including research training and support.

Received 18 March 2008 
In the first decade of the current century, there has been a fresh focus on learning spaces to accommodate blended learning and working patterns. The first wave of these developments has centred on creating effective environments for mainly undergraduate students, but it is clear that accommodation for researchers must also evolve.

\section{Space and the researcher}

Interviews conducted by the authors found that some researchers said that the virtual presence of the library rendered its physical presence less important.

The physical environment matters less in the $21^{\text {st }}$ century. (USA, Information Literacy Librarian and researcher)

Physical entity less important but existence of the holder of resources very important... (UK, Environmental Scientist)

Accessing resources is very important; the physical library less so. (UK, Senior Lecturer in Clinical Education)

However, a surprisingly large number of researchers interviewed commented on how thrilling they found the atmosphere of a big research library and how they valued the scholarly nature of the setting.

Environment is very conducive to work (Turkey, TESOL lecturer)

I like browsing, peace and tranquillity - not to feel pressurised - the atmosphere, escapism, away from the phone, no one can get you... I love the atmosphere of a library ... (UK, Professor in Industrial Statistics)

I love all the books, the feeling of the world at your fingertips, the quiet and space for study and contemplation... (USA, Assistant Professor, recent PhD)

When I worked in my first research post I had to spend time getting familiar with the area - I spent full days sometimes working in the library and I thought it was wonderful to have the space to do that. (UK, Director of Centre of Excellence, Educational Developer)

I worked to all hours in my carrel in the library on my thesis. I was so immersed, the library felt like a blessed place. (USA, Assistant Professor, recent PhD)

Certainly the LibQUAL ${ }^{\mathrm{TM}}$ survey instrument which assesses quality along four dimensions includes one dimension about how the users feel about the library as a place (Heath et al 2003, Pomerantz and Marchionini, 2007) This recognition of the importance of place taps into users' feelings about the library as a space facilitating quiet study; for solitude; for reflection; for creativity; and for contemplation.

The Research Information Network (2006) study devotes a chapter to 'A Sense of Place' and stresses the need for librarians to give careful consideration to the configuration of their space and services for researchers, for example in the provision of facilities for quiet individual study.

The information commons developments of integrated learning, study and ICT support spaces have been immensely successful. Libraries now need to turn (or 
possibly return) to creating spaces for researchers. It is less necessary for many researchers to spend the hours in libraries that they once did - digital delivery of material, combined with the provision of well-equipped spaces for research students has changed this. But although many researchers visit the library less often, it does not mean that those visits are less important, especially to researchers in the social sciences and humanities who still depend on access to monographs and printed collections. Any time spent in the Humanities reading rooms of the British Library will attest to the continuing need for library space! Table 1 suggests some space planning ideas.

\begin{tabular}{|c|c|}
\hline $\begin{array}{l}\text { Researchers } \\
\text { and their library } \\
\text { use }\end{array}$ & $\begin{array}{l}\text { Survey your research community to find out the level and } \\
\text { nature of use your researchers make of your own and other } \\
\text { libraries. }\end{array}$ \\
\hline & $\begin{array}{l}\text { Triangulate your findings from your discussions with these } \\
\text { groups with references to the literature and visits to other } \\
\text { institutions. }\end{array}$ \\
\hline $\begin{array}{l}\text { Silent study } \\
\text { spaces }\end{array}$ & $\begin{array}{l}\text { Try to find ways of designing comfortable, silent working } \\
\text { spaces which have IT access. }\end{array}$ \\
\hline $\begin{array}{l}\text { vels of } \\
\text { o ICT }\end{array}$ & $\begin{array}{l}\text { Ensure that there is enough space to work with books and } \\
\text { computers, a good power supply, high quality lighting } \\
\text { (possibly even task lighting - very popular in libraries that } \\
\text { have it) and wireless access. }\end{array}$ \\
\hline $\begin{array}{l}\text { Research } \\
\text { information } \\
\text { commons }\end{array}$ & $\begin{array}{l}\text { Is there any scope to provide researchers with spaces for } \\
\text { meetings, good levels of access to a mixture of technology } \\
\text { for presentations, information creation and publishing, a } \\
\text { mixture of study environments, including soft seating and } \\
\text { food-tolerant zones, as well as individual, reservable } \\
\text { formal study and working spaces, with some storage? }\end{array}$ \\
\hline Collections & $\begin{array}{l}\text { Are there any materials which might be located in a } \\
\text { specific researchers' space, e.g. research methods texts, } \\
\text { academic staff development materials and some reference } \\
\text { works? }\end{array}$ \\
\hline Services & $\begin{array}{l}\text { Can services such as inter-library loans and liaison staff be } \\
\text { physically located in or near a researcher's space? This } \\
\text { model can be seen in several Australian libraries }\end{array}$ \\
\hline
\end{tabular}

Table 1: Space planning ideas

Are we returning to a model of separate undergraduate and research libraries, seen in the UK in the 1960s, albeit with radically transformed notions of what the 'library' comprises? Whether you choose to do this of course depends on the resources and opportunities that you have available as well as on whether you think this is the right approach to follow.

\section{Marketing}

One of the fundamental principles of marketing concerns understanding and meeting the needs, wants and expectations of different user groups. The 
utilitarianism that governs many of our judgements - i.e. that researchers are a minority group in terms of physical use of space - is not so easy to justify when research excellence is a key competitive advantage for institutions.

Marketing does not mean merely promoting services, but a more fundamental way of aligning your organisation to the needs of its clients and stakeholders, offering the right range of services and resources in the most appropriate way. If you are working in a research library you will share responsibility for large and prestigious collections which will inevitably attract researchers. Do not forget that many libraries have resources which should be marketed to potential users. We must find ways of unlocking these hidden treasures.

Librarians should no longer take pride in the expense of storing unused and possibly even uncatalogued archives 'just in case' some lucky researcher stumbles across them. We have a professional responsibility and ethical duty to maximize access to our resources. Even more fundamentally, libraries have to be very clear about the services and resources they can provide for researchers and then market them proactively and professionally. Instead of expecting researchers to come to us, we have to be perceived as an integral part of the research community. In universities which do not have a long tradition of research, there may also be less expectation amongst researchers of the range of resources and services they can rightfully demand from their library.

Comments made by researchers in our survey emphasise how much researchers still value the research library atmosphere, a sanctuary from the telephone and office-sharing colleagues where one may browse and discover materials by serendipity. The 'wow' factor of a large research library as an 'icon', something to be proud of, and an institutional asset needs to be capitalised upon in any marketing strategy.

Promotion of resources and collections also means that research activity can be based on existing collection strengths and research proposals can be underpinned by good quality, realistic information about resources available. Table 2 includes a selection of marketing ideas drawn from existing library research support services around the world. 


\begin{tabular}{|c|c|}
\hline \multirow[t]{2}{*}{ Research portals } & $\begin{array}{l}\text { Dedicated web pages, possibly collaborative wikis for } \\
\text { research which draw together all the services and resources } \\
\text { provided }\end{array}$ \\
\hline & $\begin{array}{l}\text { Must be up-to-date and responsive to changing } \\
\text { needs/interests }\end{array}$ \\
\hline Publications & $\begin{array}{l}\text { Handbook or virtual equivalent for research staff } \\
\text { summarising all services and resources and package them } \\
\text { appropriately - possibly including a film }\end{array}$ \\
\hline \multirow[t]{2}{*}{ Communication } & $\begin{array}{l}\text { Newsletter for researchers or inclusion in discipline } \\
\text { specific research newsletters }\end{array}$ \\
\hline & $\begin{array}{l}\text { Ensure this is purposive not only promoting new resources, } \\
\text { but also providing information and advice on using other } \\
\text { libraries, Internet searching tips etc. }\end{array}$ \\
\hline \multirow[t]{2}{*}{$\mathrm{B} \log \mathrm{s}$} & $\begin{array}{l}\text { A blog for researchers providing updates on topics of } \\
\text { interest, forthcoming conferences etc. }\end{array}$ \\
\hline & $\begin{array}{l}\text { Needs to be interesting, topical and allow others to } \\
\text { contribute/comment }\end{array}$ \\
\hline $\begin{array}{l}\text { Regular targeted } \\
\text { emails }\end{array}$ & $\begin{array}{l}\text { Designated staff may want to target emails to remind } \\
\text { researchers of their readiness and ability to provide } \\
\text { specialist support and advice }\end{array}$ \\
\hline \multirow[t]{2}{*}{ Publicity } & $\begin{array}{l}\text { Leaflets and posters featuring, e.g., images from } \\
\text { manuscripts, special collections, attractive physical spaces } \\
\text { within library buildings }\end{array}$ \\
\hline & $\begin{array}{l}\text { Use them in strategic places within the library, but also } \\
\text { make them available - free or for sale - to others }\end{array}$ \\
\hline \multirow{3}{*}{$\begin{array}{l}\text { E-learning and } \\
\text { multimedia }\end{array}$} & Digital media presentations e.g. a library video/DVD \\
\hline & Filmed introduction available through researchers portal \\
\hline & $\begin{array}{l}\text { Short podcasts on topics of interests, e.g. guides, excerpts } \\
\text { from talks }\end{array}$ \\
\hline Events & Host book launches, invite speakers and hold seminars \\
\hline $\begin{array}{l}\text { Involving } \\
\text { researchers }\end{array}$ & $\begin{array}{l}\text { Work collaboratively with active researchers to develop } \\
\text { library initiatives around current or high profile research } \\
\text { activities (for example, book displays, library posters which } \\
\text { contain images from research activities) }\end{array}$ \\
\hline $\begin{array}{l}\text { Badge library } \\
\text { resources clearly }\end{array}$ & $\begin{array}{l}\text { Ensure that all electronic information sources which are } \\
\text { paid for by the library are clearly badged with the library } \\
\text { name, so that researchers are aware that they are not using a } \\
\text { freely available source }\end{array}$ \\
\hline
\end{tabular}

Table 2: Marketing ideas 


\section{eResearch and Library 2.0}

From the marketing suggestions outlined in Table 2, it becomes apparent that many libraries are harnessing the power of Web 2.0 technologies to promote their services. What do these concepts of Web 2.0 and Library 2.0 mean for library services to research?

The phrase Web 2.0, first used by Dale Dougherty of O'Reilly in 2004, refers to innovative web applications and services, including the rise of social networking tools such as weblogs, wikis and instant messaging. Enthusiasts recognize that data is as valuable as functionality and look for ways to exploit their unique data and share it with others. Web 2.0 has much to offer researchers both in practice and in its underpinning principles of collaboration and co-operation.

Library 2.0 = Web 2.0 + Library. The concept of Library 2.0 is about user-centric developments in library services, harnessing the power of social networking tools to make real differences to the ways in which users interact with their library. Current examples include the University of Huddersfield, where the library catalogue is being developed to include borrowing suggestions and serendipity, the use of wikis including Ohio University's Biz Wiki ${ }^{1}$ and Bath University's innovative wiki which allows international students to suggest and comment on books from their home country. Table 2 above suggested some marketing techniques incorporating ICTs and many libraries are developing RSS feeds and SMS messaging as ways of connecting with users. With so many complex and different technologies, what scope is there for a Research Library 2.0, developing applications which are particularly relevant to the research community?

Operationally the challenge is to establish seamless access to quite different technologies and to integrate the paid-for and free scholarly information resources with other material and services. It can be difficult to establish a median point between focusing on managing the complex array of information resources you already have and developing novel, interesting and innovative services. Yet, we must always remember that libraries often make themselves difficult to use because of the arcane rules and procedures which we establish. Should it really be necessary to teach users how to use the library catalogue effectively? Social technologies offer user-centred forms of information management which could complement our own more rational and scientific forms of knowledge organization.

The Research Information Network (2006) study found that many information sources of potential use to researchers were under-used and that researchers' awareness of new developments in scholarly communication, such as open access, is low. There is a risk that resources not immediately available will be overlooked and unread. Certainly, the interviews which the authors conducted with researchers indicated this, as one interviewee commented that:

' $E$ ' has changed the way we do research (UK, Professor in Industrial Statistics)

Two issues in particular emanated from the interviews. Firstly, the concern -

${ }^{1}$ http://www.library.ohiou.edu/subjects/bizwiki/index.php/Main_Page 
also expressed by the RIN study - that research may on occasion be limited to what is 'easy', e.g. making do with the abstract when the full text article is unavailable:

When I'm writing papers I focus more attention on the abstract-often that is as far as most people (including me) get with e journals! (UK, Environmental Scientist)

While searching, I'm mostly looking at the articles that I do have access to, and quite often not even bothering to read the abstracts of the ones that I haven't got access to, since it would take me a couple of days to receive that information anyway. If there's nothing useful in the accessible ones, I'll turn to the rest. Sad but true... (Sweden, PhD Chemistry Student)

Secondly, researchers were experiencing information overload:

I simply read more less-relevant material .... Costs and reliance on the internet have diminished the variety of materials available. (Turkey, TESOL lecturer)

Information overload, so much being published, you need to siphon off the good from the bad. Now you have to be much much more choosy - that is the biggest challenge facing us all. (UK, Professor in Industrial Statistics)

One key driver for library services identified by the Research Information Network (2006) study is direct delivery of more digital content to the researcher's desktop. This delivery needs to be coupled with more intelligent information retrieval such as that offered by semantic applications which eliminate the uncertainty of searching in the social sciences where the same concepts can be expressed in many different ways. One of our interviewees expressed the need for this:

I hate the way the interfaces are designed and the structures are constructed, which suit the librarians' mental models of running a library, but do not support browsing search strategies and the users' mental models. The user is forced to adapt and learn by heart, the logic which is meant as a tool for storing things - in order to retransform it into a logic which is usable for finding things. (Denmark, Assistant professor, Pedagogy and ICTs)

Data mining would enable the extraction of meaningful patterns from data. Visualization software would facilitate analysis of patterns of authorship, coauthorship and citation, enabling the easy tracing of the impacts of theories, ideas and individual authors. Full-text searching provides the potential to extract key sections not just from journal articles but from monographs whose contents would have otherwise been overlooked. We will have opportunities to build truly usercentred library and information services.

\section{Users of the future}

If our library and information services are going to be user-centred, we need to consider exactly who our users of the future are. Many new researchers will come from the so-called "millennial generation". These millennials, also referred to as Generation Y, digital natives or more descriptively "screenagers" (Candy, 2006) 
are defined as those born after 1982. It is suggested that this generation has particular characteristics which need to be taken into account when considering the future of library services for research. In general terms, millennials tend to be better at processing visual information and are comfortable with multitasking and with new developments in social software. Byrnko (2006) describes them as 'optimistic, adaptive, flexible, collaborative, format agnostic and forever entrepreneurial'. This does not mean that they are necessarily more expert users than older people, but they have grown up immersed in interactive technology, from gaming and mobile phones to instant messaging, and are used to switching between a wider range of digital formats, implicitly understanding their differences. Their approaches have been described by some as 'transliterate', able to switch between and across media, but perhaps with less regard for the canon and traditional academic practice than has hitherto been taken for granted.

Researchers of the future, therefore, may approach research from a different perspective. They have grown up used to collaboration and teamwork and studied in educational systems that foster the development of such important transferable skills. They also expect to be connected $24 / 7$ and have no tolerance for delays. Many are confident in the Web 2.0 environment, the 'age of the amateur' (Keen 2007), where everyone is able to publish in an "endless digital forest of mediocrity" (Keen). In terms of how this might affect libraries, Brindley (2006) suggested that millennials think analogue is static and dull, have gaps in critical thinking and research skills, can be poorly versed in technology tools or Web resources needed for academic work and are ill-acquainted with concepts of intellectual property and plagiarism.

Millennials who have search engines delivered to their desktop will not necessarily perceive the need for anyone to mediate or refine their research strategy for them. This may result in the sort of user described by Thornton and McCracken (2005):

...clients who have carried out a "comprehensive literature search", which has turned out to a quick delve into the Internet that has barely scratched the surface.

(Thornton and McCracken, 2005, 154)

Keen (2007) also introduces the concept of digital Darwinism, the survival of the loudest and most opinionated, and expresses concern that most internet users are losing the ability to distinguish between fact and fiction, amateur and expert.

Developing greater awareness of information literacy and management is seen by librarians as a core role and $42 \%$ of researchers in the Research Information Network (2006) study agreed. However there are challenges for libraries in gaining take-up and penetration of such advice and expertise. Librarians in the RIN study reported a moderate take-up rate by researchers of formal programmes in information management. Our survey did not include interviews with librarians but one researcher who had an information science background observed:

${ }^{2}$ See http://www.transliteracy.com for further details 
I do think that there is a role for formal training courses for researchers, but I speak here as one who has run such courses and found that the researchers did not realise that there was more for them to learn! (USA, Information Literacy Librarian and researcher)

The RIN study suggests that training for established researchers may need a sharper focus on the specialist needs and practices of researchers in different disciplines. And one of our interviewees pinpointed the desirability of some sort of training needs analysis:

I think it is very important to identify which kind of need different people may have. For some, it is a question of acquiring specific skills and for others the need is on a deeper level of understanding ... if people have not understood to some degree the conceptual model of a computer then skill-based formal courses will only be a short-sighted help as they will not be able to transfer the skills from one context to another. (Denmark, Assistant professor, Pedagogy and ICTs)

In our view, it is as important as ever to reflect on the knowledge and skills of your user community and never to base your practice on assumptions without evidence.

\section{Research support and the role of the librarian}

The Research Information Network (2006) study found that $84 \%$ of researchers use general search engines and $66 \%$ use specialist databases, whilst only $15 \%$ use the advice and expertise of librarians. Gratifyingly, when our interviewees were asked about their first source of help, $94 \%$ of them mentioned librarians as their first recourse. Adjectives used to describe librarians included 'patient', 'helpful' and 'knowledgeable'. Their pedagogical and subject expertise plus their ability as trainers also featured:

Librarians have "endless patience in dealing with the most inane questions - I know because I was often asking them." (UK, Environmental Scientist)

One of our librarians spontaneously gave me a two hour long private lesson in ITbased seeking...I still remember her patience and skill. She even made me a bit less scared of the whole thing! (Sweden, Researcher and Educational Developer)

An efficient librarian makes the experience memorable-especially if they go out of their way to source relevant material on one's current research (South Africa, Researcher in Tourism and Hospitality)

Unsurprisingly the future role of library and information professionals was one of the questions asked in the email stage of the RIN study survey in which researchers and librarians were asked separately how important they envisaged the following roles to be for library and information professionals in the future: 
Teacher of information literacy and related skills

Subject-based information expert (based in library building)

Subject-based information expert (embedded in department or research group)

Administrator dealing with the purchasing and delivery of information services

Custodian of print-based and digitized archives and special collections

Manager of institutional repositories of digital information

Manager of the vast datasets generated by e-science and grid-based projects

Facilitator for e-learning, supporting Virtual Learning Environments

Technology specialist, creating and managing Virtual Research Environments (to support Virtual Research Communities)

Technology specialist facilitating electronic access to information resources Manager of (non technical) metadata issues, developing and applying ontologies Information technology expert supporting the technical aspects of information provision (e.g. networks, authentication)

Specialist advisor in copyright, intellectual property rights issues and bibliometrics

\section{[Table produced from roles featured in the RIN study]}

\section{Table 3: Roles of future LIS professionals}

A number of these roles describe existing and embedded practice in supporting learning and teaching as well as traditional roles in information support, purchasing and collection management. Others are more recently established roles, notably the management and development of institutional repositories. We suspect that in the early days of the Research Excellence Framework there will also be considerable scope to provide support for bibliometrics and ways of measuring and assessing research impacts.

Some other suggested roles are not particularly novel - for example the proposal to be a departmentally-based subject information expert is an established role in health information and in other domains drawing from a strong information science tradition. It is less common in universities, where qualified staff have blended subject work with functional or supervisory roles which are tied to the library, although there are examples in Australia of a growing trend to align subject librarians more closely with the departments with which they liaise.

The Research Information Network (2006) study identified a need for dialogue between librarians and researchers to ensure the expertise of the former is developed and deployed effectively. Librarians may need to raise their profile and become 'researchers' themselves, getting embedded in the research community, gaining credibility, and collaborating as equals. While the RIN study identifies moves in the USA towards the involvement of librarians in research projects, in most cases the librarians' role is performed within the library context in that they 
are consulted by researchers rather than proactively going out to - or seeking out - researchers in their subject area. This was very much the case with the researchers to whom we spoke in the process of authoring our book.

Key to success is the need to learn from areas where we have been successful particularly in the achievements of library and information services staff in supporting the taught student experience, and to apply that expertise and other areas of our professional knowledge to more proactive engagement with research and infrastructure development. We will continue to build on our experience of converged service delivery and multi-professional partnership working.

None of these potential roles are beyond the existing skills and knowledge of people working within library and information services. What may be necessary however is for us to reorient our professional training and development, and probably on a more fundamental level, to rethink how we develop our leadership and strategic planning. There are also challenges in areas such as intellectual property and the management of digital assets which will be particular valuable in supporting e-science.

Our key professional values and knowledge must be sustained: we lose our specialisms at our peril, they just need to evolve. We must provide access to information in a wide range of forms and expert advice on finding, accessing, using and sourcing information through developing user-centred services.

\section{Concluding thoughts}

How radical are our aspirations for the future role of libraries in support of research? Our goals are perhaps not so different from those who have written before us, which we could summarize as:

- Universal and seamless access to academic knowledge and information, ranging from metadata to the curation of printed archives and special collections, including repository development;

- User-centred services that consider the needs of all stakeholder groups in their diversity and do their best to create exceptional library and information services;

- Cost-effective and efficient use of resources to maximize value and impact. Value and impact are not purely economic and utilitarian measures: we must consider the academic, educational and cultural dimensions.

The shift is in context and environment, especially technology, so although the definitions of problems and difficulties may recall previous discussions, the focus is different. The democratization of access to information - seamless access brokered through search engines most especially, and also the opportunities created by current developments in computing and networks - means that we must reconsider how we can achieve our research support goals. The challenge applies to us all - leaders in the profession, senior library and information service managers, practising librarians at every level and those planning to join the profession. We need to develop our visions, but we will also need to ensure that the vision is delivered. It may not be easy, but it should be exciting. 


\section{References}

Brindley, L. (2006) A world of contrasts: information literacy in the digital age. Lilac Conference, University of Leeds, 27-29 ${ }^{\text {th }}$ March.

Byrnko, B. (2006) Of millennials and mashups, Information Today 23 (4), 29.

Candy, P. (2006) Running amok with a chainsaw: an unexpected perspective on information literacy. Lilac Conference, University of Leeds, 27-29 ${ }^{\text {th }}$ March.

Heath, F., Kyrillidou, M., Webster, D., Choudhury, S., Hobbs, B., Lorie, M. and Flores, N. (2003) Emerging tools for evaluating digital library services: conceptual adaptations of LibQUAL $p$ and CAPM, Journal of Digital Information 4 (2). URL: http://journals.tdl.org/jodi/article/view/jodi-115/101 [accessed 12.08.08].

Keen, A. (2007) The cult of the amateur: How today's Internet is killing our culture and assaulting our economy. London: Nicholas Brealey.

Pomerantz, J. and Marchionini, G. (2007) The digital library as place, Journal of Documentation 63 (4), 505-533.

Research Information Network (2006) Researchers and discovery services: behaviour, perceptions and needs. URL: http://www.rin.ac.uk/files/Report\%20\%20final.pdf [accessed 12.08.08].

Research Information Network and Consortium of University and Research Libraries (2007) Researchers' use of academic libraries and their services. URL: http://www.rin.ac.uk/files/libraries-report-2007.pdf [accessed 12.08.08].

Thornton, S. and McCracken, C. (2005) Putting the human touch into knowledge management, Vine 35 (3) 149-155.

Webb, J., Gannon-Leary, P. and Bent, M. (2007) Providing effective library services for research. London: Facet.

\section{Acknowledgement}

The authors would like to thank the British Academy for the overseas travel grant which enabled our original paper, on which this article is based, to be presented at the seventh Performance Measures conference in Cape Town, South Africa. 